\title{
Neonatal meningitis due to Streptococcus agalactiae
}

\author{
H. EVERLEY JONES \\ O.B.E., M.B., F.R.C.P. \\ C. H. L. Howells \\ M.D., B.Sc., M.C.Path.
}

The Royal Hospital, Wolverhampton

HaEmolytic streptococci were first subdivided into groups by precipitation of specific carbohydrate (Lancefield, 1933, 1934). It soon became apparent that most serious streptococcal infections were caused by organisms of Group A. Although organisms of Group B were known to cause mastitis in cattle there was little evidence of pathogenic activity in man. Then in 1937 Colebrook \& Purdie included two examples in a description of 106 cases of puerperal fever. In the next year Fry (1938) recorded three fatal Group B infections in the puerperium and Brown (1939) published an account of four such infections, two of them puerperal. He stated that, of all strains of streptococci with $\beta$-haemolysis isolated by him, $1.6 \%$ belonged to Group B. Rantz \& Kirby (1942) described four more such infections and again drew attention to its occurrence in puerperal states. Wheeler \& Foley (1943) mentioned six patients, four of whom died, from whom this organism was isolated, but gave no clinical details. In 1947, the Commission on Acute Respiratory Disease, dealing with American recruits, reported that only $6 \%$ of hospital admissions were caused by streptococcal infection, of whom $90 \%$ were attributable to Lancefield Group A and 'a few' to Group B.

Thereafter, little was written on the subject until, in 1961, Hood, Janney \& Dameron suggested that the incidence of Group B streptococcal infection in the newborn at least was higher than had been thought. They cultured the brains of 113 non-viable foetuses and stillborn infants. Streptococcus agalactiae was recovered from nearly $10 \%$. Keitel et al. (1962) reported two newborn infants from whom the organism was isolated in the cerebro-spinal fluid. In both cases the same organism was cultured from the mothers' cervices and both babies died. Mannik et al. (1962) described a 29-day-old infant, in whom meningitis due to Group B streptococci was successfully treated. This is one of the three cases of recovery from the disease in the newborn recorded.

Eickoff (Eickoff et al., 1964) recorded seven infants from whom $\beta$-haemolytic streptococci Group B were cultured from the blood, four of whom died. In three others positive blood cultures were considered unrelated to their illnesses. In none of these babies was meningitis present. Sicherman (1965) described two siblings, aged 2 and 3 years with septicaemia, but no meningitis, from both of whom Group B streptococci were isolated from the blood.

During this latter period seven examples of Group B meningitis have been published in the continental literature (de Moor, 1960 ; Seeleman, 1941 ; Obiger, 1964 ; Kexel \& Khonhohn, 1965. De Moor's infant was the second to recover.

Finally in 1966 Winterbauer, Fortune and Eickhoff described two newborn infants with meningitis caused by this organism. These occurred within a few days of each other in a small hospital and one of them survived after treatment with penicillin and kanamycin.

No instances of Group B meningitis in the newborn have been described to date in the British Isles. We therefore report two such cases occurring in the same hospital.

\section{Case reports}

Case 1

A.S. female: this premature infant was the first born of a 17-year-old mother, and was admitted to the Premature Baby Unit when $2 \mathrm{hr}$ old, weighing $2 \mathrm{lb} 3 \mathrm{oz}$. Progress was uneventful until the 34th day when she became fretful and resentful of handling. Pallor and dyspnoea developed and there was pyrexia $\left(101^{\circ} \mathrm{F}\right)$. The extremities were slightly oedematous. Lumbar puncture produced a turbid fluid containing 3900 white blood cells $/ \mathrm{mm}^{3}$, $98 \%$ of which were neutrophils. Colomycin was given intrathecally and hydrocortisone and cloxacillin parenterally. A Gram-stained film of the CSF however revealed Gram-positive cocci in pairs and short chains, so a few hours later a second lumbar puncture was performed and penicillin given intrathecally. The cloxacillin was changed to penicillin and 
sulphadiazine. By the next day there was a profuse growth of $\beta$-haemolytic streptococci on the blood agar plate incubated at $37^{\circ} \mathrm{C}$. This strain was later shown to be of Lancefield Group B. The infant's temperature returned to normal after $12 \mathrm{hr}$ treatment, the oedema subsided and she was able to suck. Lumbar puncture was repeated on 3 successive days and penicillin given intrathecally on each occasion. Steroid therapy was stopped after 8 days and the penicillin and sulphadiazine were continued for 14 days. Recovery was uneventful and when 3 months old the child weighed $6 \mathrm{lb} 10 \mathrm{oz}$, the head circumference was $13 \frac{3}{8}$ in. and she appeared to be developing normally.

\section{Case 2}

S.H. male: this infant was delivered by the breech. The mother had a pneumococcal empyema immediately before parturition. On admission to the nursery the weight was $4 \mathrm{lb}$ $13 \mathrm{oz}$ and the head circumference $12 \frac{1}{4}$ in. He never returned to his mother and remained well until the evening of the 12th day when he refused a feed and was lethargic. The infant became grey and limp, the temperature rose to $99^{\circ} \mathrm{F}$, and an attack of apnoea developed. The pulse soon became uncountable and the respirations rapid and shallow. The fontanelle was depressed, and convulsive movements occurred.

Lumbar puncture produced a turbid fluid under low pressure. There were 390 white blood cells $/ \mathrm{mm}^{3}, 95 \%$ of which were neutrophils. The protein was $500 \mathrm{mg} / 100 \mathrm{ml}$. Cloxacillin, ampicillin and hydrocortisone given parenterally had little effect and death occurred less than $12 \mathrm{hr}$ after the first symptom.

In this case, although Gram-positive cocci were seen on the film, intrathecal therapy was not given. Death occurred before the culture report was available.

Necropsy revealed an engorged brain with a purulent basal exudate.

\section{Discussion}

In the cases described here, not only were cervical swabs negative, but there was no clinical or bacteriological evidence of uterine infection. In both cases the first signs of illness in the infant occurred many days after separation from the mother. Furthermore, in Case 2 pneumococcal empyema had occurred antenatally in the mother and considerable quantities of penicillin must have been present in the infant's blood stream at birth.

It seemed likely then that the meningitis had been acquired after delivery. Any common factor seemed to have been excluded by the fact that the babies had been nursed in separate departments (the Premature Baby Unit and the Nursery) with separate staffs. It was not altogether unexpected, therefore, that when a bacteriological search for sources and vectors was made Streptococcus agalactiae was not cultured.

The organism can however often be found in the female genital tract and Keitel found that cervical swabs from the mothers of infected infants yielded the same organism as that found in the babies' meninges. It is perhaps surprising, therefore, that Streptococcus agalactiae has not been responsible for more cases of neonatal meningitis.

Of course, the condition is often difficult to diagnose clinically. Even when the diagnosis is made it may be wrongly assumed that the infection has been caused by a Gram-negative rod. Antibiotic therapy inappropriate for a streptococcus, may therefore be prescribed. It seems important from our two cases that a Gram film should be examined immediately and penicillin given if the infant is to survive. Even so the infecting organism may sometimes be unrecognized bacteriologically, since on the Gram filmb the cocci are often in pairs, thus superficiallye resembling Streptococcus pneumoniae to the inexperienced. On culture, although the colonies themselves can be picked up more easily from the plate and have a softer consistency than those of Streptococcus pyogenes, only about half the strains show $\beta$-haemolysis. The haemolytic zone may be narrower than usual or may even be double. Sometimes greenish haemolysis is produced and occasionally the colonies may be non-haemolytic. Although the specific carbohydrate for Group B can be demonstrated by the precipitin test of Lancefield this test may not be undertaken if the cultural appearance and haemolysis are atypical. Other diagnostic criteria may therefore be helpful notably the production of a yellow, orange, or red pigment in stab cultures, growth in $40 \%$ bile agar, and the hydrolysis of sodium hippurate.

Thus neonatal meningitis due to Streptococcus agglactiae is rare and may be difficult to diagnose. It is important that the diagnosis should be made, however, so that the appropriate treatment may be given to the individual case and the true incidence of infection determined.

\section{References}

Brown, H.J. (1939) Double-zone beta-haemolytic streptococci: their cultural characteristics, serological group ing occurrence, and pathogenic significance. J. Bact. 37, 133. 
Colebrook, L. \& Purdie, A.W. (1937) Treatment of 106 cases of puerperal fever by sulpanilamide (streptocide). Lancet, ii, 1237.

Commission on Acute Respiratory Diseases (1947) Role of Lancefield Groups of beta-haemolytic streptococci in respiratory infections. New Engl. J. Med. 236, 157.

Eickhoff, T.C. Klein, J.O., Daly, A.K., Ingall, D. \& Firland, M. (1964) Neonatal sepsis and other infections due to Group B beta-haemolytic streptococci. New Engl. J. Med. 271, 1221.

FrY, R.M. (1938) Fatal infections by haemolytic streptococcus Group B. Lancet, i, 199.

Hood, M., JANNeY, A. \& Dameron, G. (1961) Beta haemolytic streptococcus Group B associated with problems of perinatal period. Amer. J. Obstet. Gynaec. 82, 809.

Keitel, H.G. Hanariman, J., Ting., Prince, L.N. \& RANDALl, E. (1962) Meningitis in the new born infant. J. Pediat. 61, 39.

KeXel, G. \& KHonhohn, S. (1965) Streptococcus alagactiae als Erreger von Säuglingsmeningitiden. Dtsch. med. Wschr. 90, 258.

LANCEFIELD, R.C. (1933) Serological differentiation of human and other groups of haemolytic streptococci. J. exp. Med. $57,571$.

LANCEFIELD, R.C. (1934) Serological differentiation of specific types of bovine haemolytic streptococci Group B. J. exp. Med. 59, 441.
MANNIK, M., Baringer, J.R. \& Stokes, J. (1962) Infections due to Group B beta-haemolytic streptococci: report of 3 cases and review of literature. New Engl.J. Med. 266, 910.

DE MOOR, C.E. (1960) Sepsis durch Sc. agalactiae. Versl. Volksgezondh. Nr. 1

OBiger, G. (1964) Zur Pathogenität von Gruppe B-Streptokokken (Sc. agalactiae) für Mensch und Rind und über experimentelle Infektionen mit humanen AgalactiaeStämmen an der bovinen Milchdrüse. Z. Hyg. Infekt, 149, 446.

RANTZ, L.A. \& KIRBY, W.M.M. (1942) Streptococcal meningitis : 4 cases treated with sulphonamides in which etiological agent was unusual streptococcus. Amer. intern. Med. 16, 716.

SeelemanN, M. (1941) Streptokokken bei Tieren und Ihre Ubertragbarkeit auf den Menschen. Ergebnisse der Hygiene Bakteriologie Immunitatsforschung und Experimentellen Therapie, Vol. 24, pp. 463-549, Verlag von Julius, Springer, Berlin.

Sicherman, M.J. (1965) Septicemia due to group B streptococcus: Report of two siblings presenting with lesions resembling erythema nodosum. Pediatrics, 36, 6, 937.

WheEler, S.M. \& Foley, G.E. (1943) A note on non group A streptococci associated with human infection. J. Bact. 46, 391.

Winterbauer, R.H., Fortune, R. \& Eickoff, T.C. (1966) Unusual occurrence of Neonatal Meningitis due to group B beta-haemolytic streptococci. Pediatrics, 38, 4, 661 .

\title{
Gas gangrene after amputation for peripheral vascular disease
}

\author{
I. G. SCHRAIBMAN* \\ F.R.C.S.(Edin.), F.R.C.S. \\ Late Casualty Surgeon, Alfred Hospital, Melbourne
}

ANAEROBIC myositis after amputation through poorly vascularized tissues is usually rapidly fatal. Although this complication has been well recorded (Ham, MacKenzie \& Loewenthal, 1964 ; Karasewick et al., 1964) it appears that it is still a cause of death which may be avoidable. Two such patients are reported who died in this hospital within the space of 3 months from gas gangrene. A therapeutic and prophylactic regime is outlined.

\section{Case reports}

\section{Case 1}

A.E.G., male, aged 84, an ex Salvation Army Officer was admitted on 9 June 1965 with established gangrene of part of the left foot which had been present for 8 weeks. This was associated with some pain, the intensity of which was difficult to gauge.

$\mathrm{He}$ was a diabetic of 10 years standing and at

\footnotetext{
*Present address: Hyperbaric Oxygen Unit, Department of Surgery, Western Infirmary, Glasgow, W.1.
}

the time of admission he was controlled on a 15 portion diet and 16 units of Lente insulin daily.

In 1958 he had been admitted with septic arthritis of the left first metatarso-phalangeal joint and again later that year with two indolent ulcers on the left foot, which lesions had gradually healed.

He was a rather frail old man. The blood pressure was $160 / 80 \mathrm{mmHg}$ and the pulse was irregular due to extrasystoles. The left foot was relatively warm, but there were no pedal pulses palpable. There was dry gangrene of the lateral border of the foot, all four lateral toes and the lateral half of the hallux.

The right foot was cold and pulseless, but there was no gangrene.

Operation: On 11 June a mid-thigh amputation was carried out under a general anaesthetic. This was the traditional operation at the site of election $25 \mathrm{~cm}$ distal to the greater trochanter. Generous skin flaps were allowed. The muscles were sutured over the end of the bone stump; 